\title{
Differences in Muslim and National Laws on Minimum Age Restrictions for Marriage in the Philippines
}

\author{
$1^{\text {st }} \mathrm{JM}$. Muslim ${ }^{1}, 2^{\text {nd }}$ Rahmatul Ummah ${ }^{2}$ \\ \{muslimin@uinjkt.ac.id ${ }^{1}$, rahmatulummah21@mhs.uinjkt.ac.id ${ }^{2}$ \} \\ UIN Syarif Hidayatullah Jakarta ${ }^{1,2}$
}

\begin{abstract}
The codification of Muslim law in the Philippines has brought Muslims to be considered increasingly different from the rule of national law. The reason is, the rules regarding the minimum age limit for marriage have differences in the rules of the two laws. This paper discusses the existence of inequalities between Muslim Law and National Law in the Philippines, especially regarding the minimum age limit for marriage. This paper argues that the inequality of the two rules is due to the different basis of their own enforcement. Muslim law contained in the Code of Muslim Personal Laws is a law that applies specifically to the Muslim community in the Philippines, this law was issued as a way to reconcile political conflicts between the government and the Muslim community referring to the rules of Islamic law. In contrast to the National Law contained in the Family Code of the Philippines, this law is based on the adoption of western and Catholic law. It is clear here that both of them already have different religious understanding bases.
\end{abstract}

Keywords: Minimum restrictions; Philippines; Muslim law; Marriage age.

\section{Introduction}

Philippines is a country with a Muslim minority population, because almost four-fifths (79.5\% or 80,304,061 people) of the total population of the Philippines (109,979,303 people) in 2015 were dominated by Roman Catholicism as the most widely practiced religion in the Philippines. Then came Islam, the religion that many followed after Roman Catholicism. Consisting of $6.01 \%$ or $6,064,744$ people of the total population of the Philippines $(109,979,303$ people) according to the 2015 census. This was followed by movements such as Iglesia ni Cristo, Buddhism and Protestant Christianity. [1]

Islam entered the Philippines around the 13th (thirteenth) century in Sulu, Southern Philippines. [2] The majority of Filipino Muslims reside in the five provinces of West Mindanao, namely Maguindanao, Lanao del Sur, Basilan, Sulu and Tawi-Tawi. Although the majority are Sunni and Shafi'i [3], there are a small number of Shi'a living in the Lanao del Sur and Zamboanga del Sur provinces of Mindanao. And many Muslims also migrated to downtown Manila and Cebu. [4]

Code of Muslim Personal Laws, is one of the results of the codification of family law in the form of laws that apply to the Filipino Muslim community and aims to enforce Muslim civil law among Muslims in this country.

In terms of the minimum age limit for marriage, the Philippines has 2 laws that regulate it. The first provision is regulated in the Family Code of the Philippines which was ratified through Executive Order No. 209, and the second provision is regulated in the Code of Muslim Personal 
Laws passed by Presidential Decree No. 1087. The rules regarding the minimum age limit for marriage regulated by these two laws are much different, where the Code of Muslim Personal Laws stipulates 15 years for males and a minimum of 12 years of age who have reached puberty for females, while the Family Code of the Philippines set the age of 18 years for both men and women.

\section{Methodology}

In this study, qualitative research methods were used to explain the minimum age limit for marriage in the Philippines which is regulated by the Muslim Family Law and the Philippine National Family Law. This study uses a normative and comparative juridical approach, where the research is conducted by describing the regulations regarding the minimum age limit for marriage in the Philippines. Then, explaining the comparison between the two regulations in the country accompanied by a systematic description of the facts regarding the minimum age limit for marriage and also the matters and factors related to it.

\section{Result and Discussion}

\subsection{Minimum Age of Marriage in Islamic Review}

In the nass, there is no rule regarding the minimum age of marriage. This is assumed as a form of leeway for humans to regulate. In essence, the minimum age limit for marriage includes the problem of ijtihâdiyyah, where there is an opportunity to ijtihad at what age a person is appropriate to marry. Marriage is one of the affairs of the relationship between humans (mu'âmalah) which is only regulated in general principles by religion. Thus, the absence of the existence of religious rules regarding the minimum age limit for marriage can be considered a blessing. [6] However, although Islamic law does not provide concrete limits regarding the minimum age for marriage, it does not mean that Islam absolutely allows marriage at a young age, namely marriage between a man and a woman who has not yet reached puberty. [7]

The scholars of schools agree that menstruation and pregnancy are proof of puberty (baligh) on a woman. Pregnancy itself occurs due to the fertilization of an ovum by a sperm. If proof of puberty for a woman is marked by menstruation, then this is the same as releasing sperm for men and is a sign of puberty (baligh) over them. In addition, in terms of physical signs in which a person reaches the baligh phase, each school has different opinions. Maliki, Shafi'i and Hanbali state that the growth of armpit hair is evidence of a person who reached the puberty (baligh). However, the Hanafi school rejects this opinion because armpit hairs are the same as other hairs on the body and there is no difference. [8]

One of the contemporary scholars, Muhammad Ali al-Shabuni, argues in his interpretation that the sign of puberty (baligh) for men is when he has dreamed, while the sign of puberty (baligh) for women according to him is when menstruating and pregnant. This opinion is in line with the opinion of the majority of scholars. [9]

If a person does not show signs of puberty (baligh) naturally as already mentioned, then the determination of puberty (baligh) for men and women can be determined based on age. This is because the sign of puberty (baligh) is not the same for everyone. Shafi'i and Hanbali equate the 
age of puberty (baligh) for boys and girls at the age of 15 years. The minimum limit at the age of 15 years in the Shafi'i school occurs on the condition that if at the age of 9 years a child has not experienced the discharge of semen, then the age of puberty occurs at the age of 15 years. [10]

If the Shafi'i and Hanbali schools set the age of 15 years for men and women as the age of puberty (baligh) for a person, this is different from the Hanafi school. According to this school, the age of puberty (baligh) for men is 18 years while for women 17 years. This opinion is the maximum age limit, because the minimum age is 12 years for boys and 9 years for girls. This is because at that age, boys have released sperm and can get pregnant, and girls have had their periods and can get pregnant. Furthermore, according to the Maliki school, the age of puberty (baligh) for both males and females is 17 years. This is based on the opinion of this school where the provisions of puberty (baligh) according to syara' are dreams, and this age is the final period in which a person will experience dreams. [11]

In addition, the Imâmiyah set the age of puberty (baligh) for boys at the age of 15 years and for girls at 9 years. This is based on the hadith of Ibn Sinan as follows.

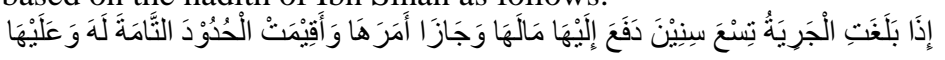

"When a girl reaches the age of 9 years, then her property is handed over to her, her business is allowed and criminal law is carried out on her rights and against her in full."

Looking the thoughts of classical scholars from several schools such as Hanafi, Maliki, Syafi'i and Hanbali, they do not make mumayyiz conditions (a position where a person can sort out what is good and bad) or maturity for the prospective bride and groom who will marry. According to them, being intelligent and baligh is enough.

From the explanation above, it can be concluded that the age of puberty (baligh) if determined by the age according to the Hanafi school is 18 years for men and 17 years for women, the Maliki school of 17 years as the age of puberty (baligh) for both, then the Shafi'i and Hanbali schools with the age of 15 years as the age of puberty (baligh) for men and women, and the last Imâmiyah with 15 years for men and 9 years for women as the age of puberty (baligh). [12]

Discussing further about the textual arguments that discuss a person's eligibility for marriage, the verse relating to this is not only found in the Qur'an Surah An-Nûr verse 32, Surah An-Nisấ verse 6 also explains about bulugh al-nikâh (arrival of time for marriage).

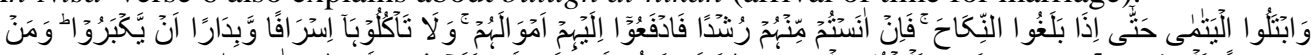

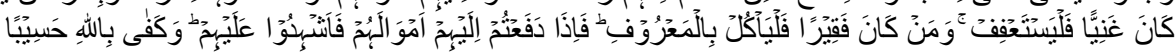

"And test the orphans until they are old enough to marry. Then if in your opinion they are intelligent (good at maintaining wealth), then hand over to them their wealth. And do not eat the property of orphans more than the limit of propriety and (do not) haste (spend) before they grow up. Whoever (among the caretakers) is able, then let him refrain (from eating the orphan's property) and whoever is poor, then let him eat the property according to what is right. Then when you hand over your property to them, then behold witnesses (about the surrender) for them. And Allah is sufficient as a Supervisor (for that testimony)."

Ibn Kathir argues that bulûgh al-nikâh (arriving at the time of marriage) is old enough or intelligent. And as for what is meant by baligh is the presence of a dream, namely a dream that in his sleep causes gushing water to come out, with that water a child occurs. [13] So in terms of arriving at the age for marriage, Ibn Kathir is not based on baligh alone, but on age and intelligence (rusyd).

Meanwhile, the views of contemporary scholars on the minimum age limit for marriage are more constructive in seeing until the time of marriage, not only on physical characteristics (bâligh), but also on the perfection of mind and soul (rusyd) by looking at the issue of the 
minimum age limit for marriage from various perspectives. . So, marriage does not only require physical maturity, but also psychological maturity, religion, social and even intellectual maturity. [14]

One of the contemporary scholars, Rashid Rida, argues that bulūgh al-nikâh means the point at which a person reaches the age to get married, that is, to dream. At this age, a person is qualified to give birth to children and produce offspring, so that he is moved to marry and at this age a person is also charged with religious laws, both worship and hudud. Therefore, the meaning of rusyd in Rashid Rida's opinion is defined as the appropriateness of a person to do tasarruf, which is to bring good and stay away from bad or evil. This is a sign of the perfection of one's mind. [15]

There are similarities between the opinions of Ibn Kathir and Rashid Rida. The opinions of Ibn Katsr and Rashid Rida both focus on the appropriateness of a person to marry, both in terms of outwardly or physically and also inwardly or mentally a person such as his attitude and behavior. In contrast to the scholars of the school of thought who argue that being reasonable and baligh is sufficient for the prospective bride and groom who will carry out the marriage.

\subsection{History of Family Law in the Philippines}

\subsubsection{Code of Muslim Personal Laws}

Enforcing the rule of family law in the Philippines is not an easy task. Starting before the Philippines became independent from its colonialists, the Muslim community, which is a minority even today, has experienced a long struggle to claim their rights. Starting from a claim regarding Muslim autonomy rights, in the end one of the results of this claim is contained in a form of legal product that becomes the foundation and reference for settlement in the realm of Muslim civil law in this country. The codification of Muslim civil law was enacted during the Sulu Sultanate of Diwan Taosug as the main rule of Sulu's civil law. Around the middle of the eighteenth century, the Sultan of Maguindanao promulgated a more complete rule, Luwaran sa Magindanao. [16] However, at that time this provision of Muslim law had not been recognized as part of Philippine state law.

In 1915, the King of the Muslim Sultanate was forced to abdicate, but was still recognized as the head of the Muslim community. In the end, in 1940 America abolished the Sultanate of Sulu and incorporated the Moros into the Philippines. [17] After the Philippines gained independence from the United States in 1946, several laws were passed and certain aspects of Muslim civil law were recognized.

The independence achieved after World War II also failed to unite the nation. On the other hand, it has led to an increase in violence. Shortly after the Philippines gained independence, the government resettled hundreds of thousands of Catholics in Mindanao, displacing the Muslim farmers who make up the majority of the population in the region and making Catholicism the dominant religious group. This demographic shift, combined with a deliberate attempt to assimilate Filipino Muslims, led to political marginalization and deprivation of rights. The Philippine government adopted a policy that allowed Muslims to retain certain customary rights while gradually eradicating Muslim practices in the southern provinces. [18]

Tensions began to rise when Filipino Muslims were deprived of the regional autonomy they enjoyed under Spanish and American rule. Disputes throughout the 1960s culminated in the Jabidah Massacre of 1968 in which Catholic officers briefly executed at least fourteen members of the Muslim military on charges of rebellion. The next criticism came from the 
Muslim population who is better known as the Moro National Liberation Front (MNLF) under the leadership of Professor Misuari, the Muslim population has experienced tremendous difficulties over the last few years because of the ferocity of the Philippine army who tried to destroy their desire to survive and live honorably as a Muslim. When violence was rampant in the south, President Marcos finally declared martial law in 1972. Instead of solving the crisis, the declaration of martial law actually sparked greater violence between the government and Islamic resistance groups. Conflict has plagued the Philippines for years after the imposition of martial law, especially in the South. [19]

The government of Ferdinand Marcos had considered a Muslim civil law system since the 1971 Constitutional Convention, but this approach to resolving the conflict did not receive serious attention until 1973 when Ferdinand Marcos issued a Memorandum Order No. 370. This memorandum established the Research Staff for the drafting of the Codification of Muslim Law of the Philippines led by Michael Mastura. The duties of the Research Staff are as follows. [20]

1) To survey, collect and gather materials on Muslim laws from all available sources with particular emphasis on current Philippine laws affected by Islamic Laws;

2) To collate and reconcile Philippine laws with Muslim laws;

3) To prepare a preliminary draft of the proposed Code of Philippine Muslim Laws (Sharia, Fiqh, Adat, etc.) and its implementing agencies.

They also undertook two months of fieldwork in eleven provinces in Mindanao and Sulu and consulted with leaders throughout the southern Philippines.

In 1974, the Research Staff proposed a draft of the Philippine Muslim Administrative Law (in this case the Code on the Administration of Muslim Law of 1974) which strongly refered to local customary law and reflected practices in Muslim areas. However, the draft received a cold reception in Manila. Not satisfied with the existing draft law, Ferdinand Marcos issued Executive Order No. 442, the substance of which is an order to establish a Presidential Commission to review the draft law. The Presidential Commission, led by a convert to Islam, Cesar Majul and formed to review the draft law, submitted a revised version on 29 August 1975. [21] The draft strengthened the supremacy of the constitution which was more in tune with practice in the Middle East. In the process, it removed most of the remnants of local customary law. [22]

In December 1976, the Republic of the Philippines and the Moro National Liberation Front (MNLF) reached a tentative peace agreement in the Tripoli Agreement. Under the terms of the agreement, the government agreed to grant greater regional autonomy to the Southern Philippines. The Tripoli Agreement did not end the conflict because it resulted in even greater autonomy for the Southern Philippines. Nonetheless, as the first meeting between the Philippine government and Muslim rebels, this agreement represents a major step in the peace process and serves as a benchmark for future negotiations, including discussions relating to the establishment of the Code of Muslim Personal Laws (CMPL). [23]

It was only on February 4, 1977, that the Code of Muslim Personal Laws was promulgated by President Ferdinand Marcos through Presidential Decree 1083 and has been in force since the date of stipulation in accordance with Article 190. Article 2 of this law states that; [24]

(a) Recognizes the legal system of the Muslims in the Philippines as part of the law of the land and seeks to make Islamic institutions more effective;

(b) Codifies Muslim personal laws; and 
(c) Provides for an effective administration and enforcement of Muslim personal laws among Muslims.

Constitutionally, the Code of Muslim Personal Laws in Presidential Decree 1083 refers to Article XV Section 11 of the 1973 Philippine Constitution:

"The State shall consider the customs, traditions, beliefs and interests of national cultural communities in the formulation and implementation of State policies."

In this article it is explained that the state must take into account the customs, traditions, beliefs and interests of the national cultural community in the formulation and implementation of state policies.

Regarding its implementation, in Article 3 paragraph (3) of the Code of Muslim Personal Laws is written:

(3) The provisions of this Code shall be applicable only to Muslims and nothing herein shall be construed to operate to the prejudice of a non-Muslim.

This article stipulates that the provisions of this law only apply to Muslims and there is nothing in this law that regulates non-Muslims.

As the title indicates, this law does not cover the entirety of sharia, only elements of civil law and does not recognize sharia as a separate and autonomous legal system. [25] More precisely, it is part of a wider justice. Consisting of 190 articles in 5 books, this law covers civil status, marriage and divorce, family relationships, child custody, wills and inheritance, customary contracts, and sharia courts.

The contents of the Code of Muslim Personal Laws are:

Table 1. Substance of Code of Muslim Personal Laws

\begin{tabular}{ccc}
\hline Part & Article & Content \\
\hline Book I & $1-7$ & General Provisions \\
Book II & $8-88$ & $\begin{array}{c}\text { Marriage, Divorce and } \\
\text { Family Relations }\end{array}$ \\
Book III & $89-136$ & Inheritance \\
Book IV & $137-168$ & $\begin{array}{c}\text { Sharia Courts and Dispute Resolution } \\
\text { Book V }\end{array}$ \\
\hline
\end{tabular}

\subsubsection{Family Code of the Philippines}

Family Code of the Philippines is a book of law that contains rules of civil law and generally applies to residents of the Philippines, except for Muslims who have been regulated by the Code of Muslim Personal Laws. Basically, the Family Code of the Philippines has been signed since July 6, 1987, and entered into force on August 4, 1988, a year after it was signed by President Corazon C. Aquino as stated in Article 265.

The Family Code replaces Book I of the Civil Code of the Philippines which was compiled with the influence of the Spanish and American colonial times [26] which was passed through the Republic Act 386. The Civil Code of the Philippines itself was first enacted in 1889, at which time the Spanish Empire still occupying the Philippines. Even when America occupied the Philippines, the Civil Code was still in effect. In 1940, President Luis Quezon ordered the creation of a commission to create a new Civil Code. However, this was halted by the Battle of Manila in 1945. 
It did not stop there, because in December 1947 under the orders of President Manuel Roxas, he formed a new commission led by Jorge Boboco which eventually finalized the final draft of the new Civil Code. This draft was eventually passed through Republic Act 386.

The ratification and establishment of the Family Code is a form of legal progress in the times in the Philippines where Book I on the Civil Code of the Philippines is no longer relevant and in accordance with Filipino culture. [27] The Family Code of the Philippines includes rules regarding marriage, marital property, rights and obligations of spouses, parental authority and adoption, and other matters relating to family relationships.

\subsection{Minimum Age of Marriage in Philippine Law}

\subsubsection{Code of Muslim Personal Laws}

With regard to the provision of minimum age limits for marriage, in Article 16 of the Code of Muslim Personal Laws regulated:

Article 16. Capacity to contract marriage.

(1) Any Muslim male at least fifteen years of age and any Muslim female of the age of puberty or upwards and not suffering from any impediment under the provisions of this Code may contract marriage. A female is presumed to have attained puberty upon reaching the age of fifteen.

(2) However, the Shari'a District Court may, upon petition of a proper guardian, order the solemnization of the marriage of a female who though less than fifteen but not below twelve years of age, has attained puberty.

(3) Marriage through a guardian by a minor below the prescribed ages shall be regarded as betrothal and may be annulled upon the petition of either party within four years after attaining the age of puberty, provided no voluntary cohabitation has taken place and the guardian who contracted the marriage was other than the father or paternal grandfather.

In paragraph (1), it is regulated that the minimum age for marriage is 15 years for men and the age of puberty or more for women. It was also explained that the age of female puberty is when it has reached 15 years.

Then, paragraph (2) stipulates that if a woman who wants to get married but has not reached the age of 15 years but is not under 12 years old and has reached puberty, may marry as long as she gets a request from a guardian and is permitted by the court.

Furthermore, paragraph (3) stipulates that marriage performed by children under the specified age can be considered as engagements and can be annulled within four years after reaching the age of puberty. This can be done as long as the couple does not live in the same house and the marriage is carried out without the guardianship of the father or paternal grandfather.

So, it can be concluded that in the Code of Muslim Personal Laws, the minimum age limit for marriage for the Muslim community in the Philippines is 15 years for both men and women, and a minimum of 12 years and puberty for women with the approval of the guardian. 


\subsubsection{Family Code of the Philippines}

Regarding the minimum age limit for marriage, Article 5 of the Family Code of the Philippines states:

"Any male or female of the age of eighteen years or upwards not under any of the impediments mentioned in Articles 37 and 38, may contract marriage."

This article stipulates that any man or woman who is eighteen years of age or older and is not subject to any of the obstacles mentioned in Articles 37 and 38, can marry.

Regarding Articles 37 and 38 which are mentioned in Article 5 of the Family Code of the Philippines, it stipulates that the marriage mentioned below is incestuous and null and void from the start, whether the relationship between the parties is legal or not.

Article 37. Marriages between the following are incestuous and void from the beginning, whether relationship between the parties be legitimate or illegitimate:

(1) Between ascendants and descendants of any degree; and

(2) Between brothers and sisters, whether of the full or half blood.

Article 38. The following marriages shall be void from the beginning for reasons of public policy:

(1) Between collateral blood relatives whether legitimate or illegitimate;

(2) Between step-parents and step-children;

(3) Between parents-in-law and children-in-law;

(4) Between the adopting parent and the adopted child;

(5) Between the surviving spouse of the adopting parent and the adopted child;

(6) Between the surviving spouse of the adopted child and the adopter;

(7) Between an adopted child and a legitimate child of the adopter;

(8) Between adopted children of the same adopter; and

(9) Between parties where one, with the intention to marry the other, killed that other person's spouse, or his or her own spouse.

Looking at the substance of Article 5 in the Family Code of the Philippines, it can be concluded that the minimum age limit for marriage for non-Muslim residents in the Philippines is equal, namely 18 years for both men and women.

The different provisions of the minimum age limit for marriage between the Family Code of the Philippines and the Code of Muslim Personal Laws also indicate differences in legal treatment between the Family Code of the Philippines and the Code of Muslim Personal Laws. According to the author's understanding, the difference in legal treatment between the Family Code of the Philippines and the Code of Muslim Personal Laws actually occurs because of the different basis for enforcement of the two laws themselves. The Family Code of the Philippines applies comprehensively to non-Muslim communities in the Philippines, while the Code of Muslim Personal Laws is a law that applies specifically to Muslim communities in the Philippines. The law, which was issued as a way to reconcile political conflicts between the government and the Muslim community, refers to the rule of Islamic law, in contrast to the Family Code of the Philippines which was compiled based on the adoption of western and Catholic law. It is clear here that both of them already have different religious understanding bases. For example, such as the prohibition of divorce and polygamy in the Family Code of the Philippines, which is contrary to Islamic law which allows both. Also regarding the provisions on the minimum age limit for marriage, which is much different between the two, where the Family Code of the Philippines stipulates the age of 18 years and the Code of Muslim Personal Laws stipulates the age of 15 for both men 
and women and a minimum of 12 years and has reached puberty for women who have not yet been married, reach 15 years but want to get married.

\section{Conclusion}

Both provisions of the Code of Muslim Personal Laws and the Family Code of the Philippines regulate the minimum age for marriage. However, the age set by the two rules is much different. The Code of Muslim Personal Laws in its rules stipulates 15 years for boys and a minimum of 12 years for girls who have reached puberty. While the Family Code of the Philippines stipulates in its law the minimum age limit for marriage for men and women is 18 years.

\section{References}

[1] Statistics Authority, Philippines. 2015 Census of Population: Report No. 2 - Demographic and Socioeconomic Characteristics Philippines. Quezon City: PSA. 2017.

[2] Rehayati, Rina. "Muslim Minorities: Learning from the case of Muslim Minorities in the Philippines." Usuluddin Journal, Vol. XVII No. July 2nd. 2011.

[3] An-Na'im, Abdullahi A. Islamic Family Law in a Changing World: A Global Resource Book. London, New York: Zed Books Ltd. 2002

[4] Department of State, Bureau of Democracy. Human Rights and Labor, United States. Philippines 2014 International Religious Freedom Report. US: United States Department of State. Bureau of Democracy, Human Rights and Labor. 2014.

[5] Gershman, John. Map and Prospects of the Islamic Movement in the Philippines in: Southeast Asia A New Concentration of Islamic Awakening. Bandung: Focusmedia. 2003.

[6] Wafa, Moh. Ali. Marriage Law in Indonesia: A Study in Islamic Law and Material Law. South Tangerang: Modern Indonesian Asy-Shari'ah Foundation. 2018.

[7] Wafa, Moh. Ali. "A Critical Study of Early Marriage According to Islamic Law." Ahkam: Journal of Sharia Science, Vol. 17 No. 2. 2017.

[8] Mughniyah, Muhammad Jawad. Fiqh of the Five Schools: Ja'fari, Hanafi, Maliki, Shafi'i and Hanbali. trans. Masykur AB, Afif Muhammad, Idrus Al-Kaff. Jakarta: Lantern. 2011.

[9] Al-Shabuni, Muhammad Ali. Tafsir Ayat al-Ahkam min Al-Qur'an. Beirut: Dar al-Kutub al'Ilmiyyah. 1999.

[10] Al-Zuhaili, Wahbah. al-Figh al-Islam wa Adilatuhu. Juz III. Damascus: Daar al-Fikr. 1985.

[11] 'Well, Abdul Qadir. al-Tasyri' al-Jinâi al-Islâmi Juz 1. Cairo: Dar al-Urubah. 1964.

[12] Mughniyah, Muhammad Jawad. Fiqh of the Five Schools: Ja'fari, Hanafi, Maliki, Shafi'i and Hanbali. trans. Masykur AB, Afif Muhammad, Idrus Al-Kaff. Jakarta: Lantern. 2011.

[13] Katsr, Ibn. Tafsir al-Qur'ân al-'Azim, Juz IV. Egypt: Dar al-Kutub. 1998.

[14] Hatta, Moh. "Age of Marriage in the Perspective of Classical and Contemporary Scholars." AlQānn, Vol. 19 No. 1. June 2016.

[15] Athaillah, A. Concepts of Rational Theology in Tafsir Al-Manar. Jakarta: Primary Literacy Festival. 2006.

[16] Journalism and Communication, Asian Institute. A Primer on The Code of Muslim Personal Laws of The Philippines. Manila: The Asia Foundation. 2007.

[17] Kettani, M. Ali. Muslim Minorities in Today's World. Jakarta: PT. RajaGrafindo Persada. 2005. [18] Holbrook, Justin. "Legal Hybridity in the Philippines: Lessons in Legal Pluralism from Mindanao and the Sulu Archipelago." SSRN Electronic Journal, 2009. 
[19] Francia, Luis H. A History of the Philippines: from Indios Bravos to Filipinos. New York, Overlook Press. 2010.

[20] Memorandum of Order No. 370 (Created under Executive Order No. 411, 1973), August 13, 1973, Official Gazette (Official Journal of the Republic of the Philippines).

[21] Bentley, G. Carter. "Islamic Law in Christian Southeast Asia: The Politics of Establishing Sharia Courts in the Philippines." Philippines Studies, Vol. 29 No. 1. 1981.

[22] Stephens, Matthew. "Islamic Law in The Philippines: Between Appeasement and Neglect." ARC Federation Fellowship, Melbourne Law School, 2011.

[23] Ringuet, Daniel Joseph. "The Continuation of Civil Unrest and Poverty in Mindanao." Contemporary Southeast Asia, Vol. 24 No. 1. 2002.

[24] Code of Muslim Personal Laws of the Philippines (Promulgated under Presidential Decree No. 1083), Article 16 Section 1, 4 Februari 1977, Official Gazette (Official Journal of the Republic of Philippines).

[25] Constitution of the Republic of Philippines 1973, Article XV Section 11, 17 Januari 1973, Official Gazette (Official Journal of the Republic of Philippines).

[26] Civil Code of the Philippines (Promulgated under Republic Act No. 386), 18 Juni 1949, Official Gazette (Official Journal of the Republic of Philippines).

[27] Sempio-Diy, Alicia. Handbook on the Family Code of the Philippines. Quezon City: Central Lawbook Publishing. 1988. 